\title{
Diversitas Tumbuhan Buah Lokal Pada Areal Tembawang Desa Engkersik Kabupaten Sekadau
}

\author{
Ria Rosdiana Hutagaol \\ Fakultas Pertanian Universitas Kapuas Sintang \\ Email : riarose.h@gmail.com
}

\begin{abstract}
Abstrak : Penelitian ini dilaksanakan di Areal Tembawang yang terdapat di Desa Engkersik Kabupaten Sekadau Kalimantan Barat. Penelitian ini bertujuan untuk mengetahui diversitas tumbuhan buah lokal di areal Tembawang Desa Engkersik Kabupaten Sekadau Kalimantan Barat. Untuk mendapatkan jenis-jenis tumbuhan buah lokal dilakukan pengamatan pada transek yang ditentukan secara purposive. Hasil identifikasi menunjukkan bahwa terdapat 15 jenis tumbuhan buah lokal pada areal Tembawang Desa Engkersik pada berbagai habitus yaitu semai, pancang, tiang dan pohon. Hasil analisis vegetasi menunjukkan bahwa INP tertinggi terdapat pada jenis durian habitus pohon dengan INP sebesar 101,58. Indeks Keanekaragaman (H') tertinggi dimilik oleh jenis durian dengan nilai H' sebesar 1,31.
\end{abstract}

Kata Kunci : Diversitas, Tumbuhan Lokal, Tembawang

PENDAHULUAN

$$
\begin{aligned}
& \text { Tumbuhan buah lokal } \\
& \text { merupakan salah satu potensi yang } \\
& \text { terdapat pada hutan Kalimantan Barat. } \\
& \text { Tumbuhan buah lokal Kalimantan } \\
& \text { merupakan tanaman yang tumbuh liar di } \\
& \text { hutan dan berbuah umumnya satu tahun } \\
& \text { satu kali dengan masa musim berbuah } \\
& \text { yang cukup pendek (Antarlina, 2009). } \\
& \text { Umumnya tumbuhan buah lokal } \\
& \text { tersebut memiliki rasa asam manis dan } \\
& \text { dapat dikonsumsi sebagai buah meja } \\
& \text { seperti belimbing merah, langsat dan } \\
& \text { durian. Namun buah lokal yang } \\
& \text { memiliki rasa asam yang cukup kuat } \\
& \text { akan digunakan sebagai campuran pada } \\
& \text { sayur olahan untuk menambah cita rasa } \\
& \text { makanan (Susi, 2014). }
\end{aligned}
$$

Tumbuhan buah lokal Kalimantan pada umumnya semakin berkurang jenis dan populasinya akibat kurangnya upaya budidaya terhadap tumbuhan buah lokal tersebut. Kelangkaan tanaman juga disebabkan oleh umur berbuah yang lama.

Diversitas atau keanekaragaman jenis tumbuhan buah lokal menunjukkan berbagai variasi dalam bentuk, struktur tubuh, warna, jumlah dan sifat lain dari tumbuhan buah lokal di suatu daerah. Diversitas dapat dilihat dari adanya persaamaan dan perbedaan ciri yang terdapat pada tumbuhan buah lokal tersebut.

Masyarakat di Kalimantan pada umumnya mengelola tumbuhan 
buah lokal pada suatu lahan yang disebut dengan istilah Tembawang. Tembawang yang merupakan sistem penggunaan lahan di masyarakat Suku Dayak, Kalimantan Barat dianggap sebagai ekosistem yang unik karena menyimpan nilai-nilai yang sangat tinggi. Tidak hanya sekedar memiliki keanekaragaman hayati yang tinggi, tetapi juga mengandung nilai ekonomi dan nilai moral konservasi.

Tembawang atau sering disebut sebagai agroforest tembawang adalah suatu bentuk sistem penggunaan lahan yang terdiri dari berbagai jenis tumbuhan, mulai dari pohon-pohon besar berdiameter lebih dari 100 sentimeter hingga tumbuhan bawah sejenis rumput-rumputan. Sistem ini dikelola dengan teknik-teknik tertentu sesuai dengan kearifan lokal mereka dan mengikuti aturan-aturan sosial sehingga membentuk keanekaragaman yang kompleks menyerupai ekosistem hutan alam.

Di masa lalu, sebagian besar masyarakat Suku Dayak memiliki pola pemukiman berpindah-pindah mengikuti pola perpindahan ladang mereka. Di lokasi pemukiman tersebut mereka menanam berbagai jenis tanaman yang mereka anggap menjadi sumber bahan makanan, bumbubumbuan dan tanaman buah-buahan seperti durian, mangga, rambutan, manggis dan entawak. Seiring dengan berjalannya waktu, merekapun menanam tanaman karet dan tengkawang di lokasi tersebut. Namun demikian, tidak semua tumbuhan yang ada di dalam sistem agroforest tembawang adalah hasil penanaman, ada juga tumbuhan yang tumbuh secara alami dalam proses regenerasi alam seperti nyatuh, jenis-jenis rotan, tumbuhan merambat (liana), tumbuhan semak dan herba, bahkan jenis-jenis anggrekpun kebanyakan tumbuh secara alami.

Untuk mendapatkan informasi yang jelas mengenai jenis-jenis tumbuhan khususnya tumbuhan buah lokal pada areal tembawang Desa Engkersik maka perlu dilakukan kajian mengenai tumbuhan buah lokal di areal tersebut.

\section{METODE PENELITIAN}

Penelitian ini dilakukan pada Bulan September 2017, merupakan penelitian deskriptif kuantitatif dengan teknik pengumpulan data berupa transek yang diletakkan secara purposive di areal tembawang. Transek 
digunakan untuk pengumpulan data jenis dan jumlah individu masingmasing jenis tiap habitus. Identifikasi dilakukan untuk mengetahui ciri-ciri morfologis dari masing-masing jenis tumbuhan lokal yang ditemukan. Untuk mengetahui Indeks Nilai Pennting dan Indeks Keanekaragaman Jenis ( $\left.\mathrm{H}^{\prime}\right)$ dilakukan analisis vegetasi dengan rumus sebagai berikut :

a. Analisis Diversitas Shannon-Wiener :

$$
\mathrm{H}^{\prime}=-\sum_{i=1}^{s}(p i)(\ln . p i)
$$

dimana :

$\mathrm{H}^{\prime}=$ Nilai indeks diversitas Shannon-Wiener

$\mathrm{Pi}=$ Proporsi dari tiap jenis ke-i

$\mathrm{s}=$ jumlah jenis yang teramati

Kriteria indeks diversitas Sannon-Wiener adalah :

$\mathrm{H}^{\prime}<1 \quad$ : tingkat diversitas /keanekaragaman jenis rendah

$1<\mathrm{H}^{\prime}<3$ : tingkat diversitas/keanekaragaman jenis sedang

$\mathrm{H}^{\prime}>3$ : tingkatdiversitas/keanekaragaman jenis tinggi

b. Analisis Indeks Nilai Penting (INP) :

Untuk mengetahui INP maka terlbih dahulu harus mengetahui nilai Kerapatan

Relatif (KR), Frekuensi Relatif (FR), dan Dominansi Relatif (DR), dengan rumus :

$\mathrm{KR}=\frac{\text { Kerapatan suatu jenis }}{\text { kerapatan seluruh jenis }} \times 100 \%$

$\mathrm{FR}=\frac{\text { Frekuensi suatu jenis }}{\text { Frekuensi Seluruh Jenis }} \times 100 \%$
$\mathrm{DR}=\frac{\text { Dominansi suatu jenis }}{\text { Dominansi seluruh jenis }} \times 100 \%$

$\mathrm{INP}=\mathrm{KR}+\mathrm{FR}+\mathrm{DR}$ (untuk tingkat Pohon dan Tiang)

$\mathrm{INP}=\mathrm{KR}+\mathrm{FR}$ (untuk tingkat pancang dan semai) 


\section{HASIL DAN PEMBAHASAN}

A. Tumbuhan Buah Lokal di Areal Tembawang Desa Engkersik

Hasil pengamatan yang dilakukan di tiga Tembawang Desa

Engkersik Kabupaten Sekadau, yaitu
Tembawang Baru Lebur, Tembawang Engkersik 1 dan Tembawang Suak Terentang diperoleh 15 jenis tumbuhan buah lokal seperti pada Tabel 1. berikut ini :

Tabel 1. Jenis Tumbuhan Buah Lokal Di Areal Tembawang Desa Engkersik

\begin{tabular}{|l|l|l|}
\hline \multicolumn{1}{|c|}{ Nama Lokal } & \multicolumn{1}{|c|}{$\begin{array}{c}\text { Nama dalam Bahasa } \\
\text { Indonesia }\end{array}$} & \multicolumn{1}{|c|}{ Nama Ilmiah } \\
\hline Derian & Durian & Durio zibethinus \\
\hline Mangis & Manggis & Garcinia mangostana \\
\hline Lengkuis & Lengkeng & Dimocarpus logan \\
\hline Entawok & Mentawak & Arthocarpus anisophyllus \\
\hline Blitek & Rambutan & Nephelium lappaceum \\
\hline Lingsat & Langsat & Lansium domesticum \\
\hline Peluntan & Peluntan & Arthocarpus elastis \\
\hline Kemayau & Kemayau & Canarium kadondon \\
\hline Kemantan & Kemantan & Mangifera odorata \\
\hline Asam Pelam & Asam Pelam & Mangifera indica \\
\hline Panau & Panau & Garcinia sp. \\
\hline Ucung & Belimbing Darah & Baccaurea angulata \\
\hline Pekawai & Pekawai & Durio kutajensis \\
\hline Tebedak & Cempedak & Arthocarpus champedens \\
\hline Ramai & Rambai & Baccaurea montleyana \\
\hline Sumber : Data & , & \\
\hline
\end{tabular}

Sumber : Data Hasil Penelitian, 2017

B. Diversitas / Keanekaragaman Jenis Tumbuhan Buah Lokal

a. Indeks Nilai Penting (INP)

Hasil pengamatan dan pengambilan data di lapangan berupa nama jenis, jumlah jenis dan jumlah individu masing-masing jenis tumbuhan buah lokal, kemudian dilakukakan analisis vegetasi untuk mengetahui Indeks Nilai Penting (INP). Berdasarkan hasil perhitungan INP, maka 
diketahui bahwa tumbuhan durian pada tingkat/habitus pohon termasuk kedalam INP dengan kriteria sedang. Tumbuhan jenis lain (14 jenis) memiliki INP dengan kriteria rendah.

b. Indeks Keanekaragaman Jenis Shannon-Wiener

(H') tumbuhan buah lokal pada aeral tembawang tergolong kedalam kategori rendah sampai dengan sedang, namun sebagian besar termasuk kedalam kategori rendah $\left(\mathrm{H}^{\prime}<1,0\right)$. Tumbuhan buah lokal yang memiliki indeks diversitas/ keanekaragaman jenis tertinggi adalah jenis durian dengan nilai $H^{\prime}=1,31$ dan termasuk $\mathrm{ke}$ dalam kategori sedang. Hal ini menunjukkan bahwa jenis durian masih banyak terdapat di areal tembawang Desa Engkersik. Adapun indeks diversitas yang paling rendah adalah untuk jenis Pekawai pada habitus pohon dengan nilai $\mathrm{H}^{\prime}=0,07$.
SARAN

Berdasarkan penelitian disarankan bahwa perlu kajian lebih lanjut khususnya tentang pemanfaatan tumbuhan buah lokal oleh masyarakat setempat

\section{DAFTAR PUSTAKA}

Antarlina,S., 2009. Identifikasi Sifat Fisik dan Kimia BuahBuahan Lokal Kalimantan. Buletin Plasma Nutfah Vol.15 No.2 tahun 2009.

Indriyanto.2006. Ekologi Hutan. Jakarta : Bumi Aksara

Rizal, M., Pamuji S.R., Supriyono, A. 2015 Prospek Pengembangan Buah Lai (Durio kutajensis) Sebagai Varietas Unggul Lokal di Kabupaten Kutai Kartanegara Kaltim. Prosiding Seminar Nasional Masyarakat Biodiversitas Indonesia 1 (6): 1497-1501.

Susi. 2014. Potensi Pemanfaatan Nilai Gizi Buah Eksotik Khas Kalimantan Selatan. Jurnal Ziraa'ah. Vol. 39 N0.3 Tahun 2014. Universitas Lambung Mangkurat Banjarmasin.

Tjitrosoepomo, G. 2005. Taksonomi

Umum. Yogyakarta : Gadjah Mada University Press. 


\title{
Pemberian Air Beras Terhadap Pertumbuhan Dan Hasil Tanaman Sawi (Brassica juncea L.)
}

\author{
Markus Sinaga \\ Fakultas Pertanian Universitas Kapuas Sintang. \\ e-mail : markusagronomi@yahoo.co.id
}

\begin{abstract}
Abstrak: Air beras merupakan salah satu bahan organik yang dapat menyumbangkan unsur hara bagi tanaman, pemberian pada tanaman sawi dapat dilakukan dengan cara menyiramkan di sekitar perakaran tanaman. Penelitian ini bertujuan untuk mengetahui pengaruh air beras terhadap pertumbuhan dan hasil tanaman sawi, dan mengetahui volume air cucian beras yang menghasilkan pertumbuhan dan hasil tanaman sawi tertinggi. Variabel bebas: air beras. Variabel terikat: tinggi tanaman, jumlah daun, dan berat segar tanaman. Penelitian ini dilakukan dengan metode eksperimen lapangan, rancangan lingkungan yang digunakan dengan pola Rancangan Acak Kelompok (RAK). Faktor perlakuan dalam penelitian ini adalah pemberian air beras (B) yang terdiri dari 5 taraf perlakuan dengan 5 kali pengulangan. Adapun taraf perlakuan terdiri dari: $\mathrm{b}_{0}$ (tidak diberi air beras), $b_{1}\left(0,25\right.$ liter air beras per $\left.\mathrm{m}^{2}\right), \mathrm{b}_{2}\left(0,5\right.$ liter air beras per $\left.\mathrm{m}^{2}\right), \mathrm{b}_{3}(0,75$ liter air beras per $\left.\mathrm{m}^{2}\right)$, dan $\mathrm{b}_{4}\left(1\right.$ liter air beras per $\left.\mathrm{m}^{2}\right)$. Data dianalisis dengan analisis ragam dan dilajutkan dengan uji BNJ. Hasil penelitian diketahui bahwa: Pemberian air beras berpengaruh tidak nyata terhadap pertumbuhan sawi yang diketahui dari hasil pengamatan tinggi tanaman, tetapi berpengaruh nyata terhadap jumlah daun dan berat segar tanaman. Volume siraman air beras 0,5 liter menghasilkan jumlah daun dan berat segar tertinggi dengan rata-rata 9,80 helai per tanaman, dan 127,00 gram per tanaman.
\end{abstract}

Kata Kunci: Air beras, pertumbuhan, hasil, sawi.

\section{PENDAHULUAN}

Sawi hijau (Brassica juncea L.) merupakan sumber vitamin A, K, dan E, karoten, xanthin serta kaya akan antioksidan dan mineral yang sangat baik untuk tubuh. Sawi hijau memiliki kalori yang rendah dan batangnya mengandung serat larut dan tidak larut. Pengembangan sawi hijau pada tanah PMK perlu disiasati dengan cara penambahan bahan organik karena tanah ini kandungan bahan organik yang rendah. Secara umum tanah ini dikenal dengan tanah yang relatif miskin akan bahan organik dan memiliki kandungan $\mathrm{Al}$ dan $\mathrm{Fe}$ yang cukup tinggi, tetapi jika dikelola dengan baik tanah ini masih dapat memberikan produksi yang optimal bagi tanaman.

Salah satu cara agar tanah PMK dapat dikelola untuk budidaya tanaman sawi adalah dengan memberikan air beras. Air beras memiliki kandungan nutrisi yang berlimpah, yang dapat berfungsi sebagai pengendali organisme pengganggu tanaman yang ramah lingkungan serta banyak dijumpai di lingkungan sekitar. Kandungan nutrisi 
yang ada pada air cucian beras di antaranya adalah karbohidrat berupa pati (85-90\%), protein glutein, selulosa, hemiselulosa, gula dan vitamin yang tinggi. Selain itu, formulasi air cucian beras merupakan media alternatif pembawa $P$. fluorescens yang berperan dalam pengendalian patogen penyebab penyakit karat dan pemicu pertumbuhan tanaman (Yayu, 2011).

Selama ini air cucian beras sebagian besar tidak dimanfaatkan secara optimal, bahkan langsung dibuang begitu saja. Bagi tanaman air beras dapat membantu meningkatkan pertumbuhan tanaman.

Pemberian air beras dalam meningkatkan pertumbuhan dan hasil tanaman perlu diperhatikan takaran yang tepat (volume siram), karena volume siram yang berlebihan menyababkan ketidak efektifan bagi tanaman. Juga sebaliknya, jika volume siramnya rendah tidak akan memberikan efek pertumbuhan seperti yang diharapkan. Oleh sebab itu maka volume siram yang tepat perlu diperhatikan.

Penelitian ini bertujuan untuk mengetahui: (1) Pengaruh pemberian air beras terhadap pertumbuhan serta hasil tanaman sawi hijau. (2) Volume siram air beras yang menghasilkan pertumbuhan dan hasil tanaman sawi hijau tertinggi. Ruang lingkup penelitian ini: air beras sebagai variable bebas. Tinggi tanaman, jumlah daun, dan berat segar tanaman sebagai variable terikat.

\section{METODE PENELITIAN}

Penelitian ini dilakukan dengan metode eksperimen lapangan, rancangan lingkungan yang digunakan dengan pola Rancangan Acak Kelompok (RAK). Faktor perlakuan dalam penelitian ini adalah pemberian air beras (B) yang terdiri dari 5 taraf perlakuan dengan 5 kali pengulangan. Adapun taraf perlakuan terdiri dari:kontrol $\left(b_{0}\right), 0,5$ liter air beras $\left(b_{1}\right)$, 1 liter air beras $\left(b_{2}\right), 1,5$ liter air beras $\left(b_{3}\right)$, dan 2 liter air beras $\left(b_{4}\right)$.

Data hasil pengamatan dianalisis dengan uji $\mathrm{F}$ kemudian dilanjutkan dengan uji BNJ pada selang kepercayaan 0,05 dan 0,01.

\section{HASIL}

Hasil pengamatan pemberian air beras terhadap peubah yang diamati tertera pada Tabel 1. 
Tabel 1. Rerata hasil pengamatan pemberian air beras terhadap peubah tinggi tanaman, jumlah daun, danberat segar tanaman

\begin{tabular}{cccc}
\hline \multirow{2}{*}{ Perlakuan } & \multicolumn{3}{c}{ Rerata } \\
\cline { 2 - 4 } & tinggitanaman $(\mathbf{c m})$ & jumlah daun (helai) & berat segar $(\mathbf{g})$ \\
\hline $\mathrm{b}_{0}$ & 33,85 & 8,75 & 92,00 \\
$\mathrm{~b}_{1}$ & 36,33 & 9,55 & 113,50 \\
$\mathrm{~b}_{2}$ & 37,35 & 9,80 & 127,00 \\
$\mathrm{~b}_{3}$ & 34,73 & 8,80 & 100,00 \\
$\mathrm{~b}_{4}$ & 36,18 & 10,10 & 105,50 \\
\hline
\end{tabular}

Sumber: Data pengamatan, 2017.

Data dalam Tabel 1 ditampilkan rerata tinggi tanaman tertinggi terlihat pada tanaman $b_{2}$ dengan tinggi rata-rata $37,35 \mathrm{~cm}$, sedangkan tinggi tanaman terendah pada tanaman $\mathrm{b}_{0}$ dengan tinggi rata-rata $33,85 \mathrm{~cm}$. Jumlah daun terbanyak pada tanaman $\mathrm{b}_{4}$ dengan ratarata 10,10 daun per tanaman, sedangkan jumlah daun terendah pada tanaman $\mathrm{b}_{0}$ dengan jumlah rata-rata 8,75daun per tanaman. Berat segar tanaman tertinggi pada tanaman $b_{2}$ dengan berat rata-rata
$127,00 \mathrm{~g}$ per tanaman, sedangkan berat segar tanaman terendah pada tanaman $\mathrm{b}_{0}$ dengan berat rata-rata $92,00 \mathrm{~g}$ per tanaman.

Hasil uji $\mathrm{F}$ diketahui bahwa pemberian air beras tidak berpengaruh nyata terhadap peubah tinggi tanaman, tetapi pengaruh nyata terlihat pada peubah jumlah daun, dan berat segar tanaman, seperti yang terlihat dalam Tabel 2.

Tabel 2. Uji F pemberian air beras peubah tinggi tanaman, jumlah daun, sertaberat segar tanaman

\begin{tabular}{cccccc}
\hline \multirow{2}{*}{ SK } & \multicolumn{3}{c}{ F hitung } & \multicolumn{2}{c}{ F tabel } \\
\cline { 2 - 6 } & $\begin{array}{c}\text { Tinggi tanaman } \\
(\mathbf{c m})\end{array}$ & jumlah daun & $\begin{array}{c}\text { berat segar } \\
(\mathbf{g})\end{array}$ & $\mathbf{0 , 0 5}$ & $\mathbf{0 , 0 1}$ \\
\hline Kelompok & $4,57^{*}$ & $0,58^{\mathrm{tn}}$ & $6,59^{* *}$ & 3,01 & 4,77 \\
Perlakuan & $1,16^{\mathrm{tn}}$ & $3,42^{*}$ & $3,32^{*}$ & 3,01 & 4,77 \\
\hline
\end{tabular}

$\begin{aligned} \text { Keterangan : tn } & =\text { tidak nyata pada taraf } 0,05 \\ * * & =\text { nyata pada taraf } 0,01\end{aligned}$ 
Tabel 3. Uji BNJ pemberian air beras terhadap peubah jumlah daun, danberat segar tanaman

\begin{tabular}{|c|c|c|}
\hline Perlakuan & Jumlahdaun (helai) & Berat segar tanaman (g) \\
\hline $\mathrm{b}_{0}$ & $8,75 \mathrm{a}$ & $92,00 \mathrm{a}$ \\
\hline $\mathrm{b}_{3}$ & $8,80 \mathrm{a}$ & $100,00 \mathrm{ab}$ \\
\hline $\mathrm{b}_{1}$ & $9,55 \mathrm{~b}$ & $113,50 \mathrm{c}$ \\
\hline $\mathrm{b}_{2}$ & $9,80 \mathrm{~b}$ & $127,00 \mathrm{~d}$ \\
\hline $\mathrm{b}_{4}$ & $10,10 \mathrm{~b}$ & $105,50 \mathrm{bc}$ \\
\hline BNJ 0,05 = & 0,59 & 13,40 \\
\hline BNJ 0,01 = & 0,77 & 17,24 \\
\hline
\end{tabular}

Keterangan : angka yang ditandai huruf sama menunjukkan tidak beda nyata pada taraf 0,05

Hasil uji BNJ seperti yang terlihat dalam Tabel 3 diketahui bahwa pemberian air beras 2 liter tidak menghasilkan jumlah daun yang lebih baik dari tanaman yang diberi 1 liter dan 0,5 liter, tetapi lebih banyak dari jumlah daun tanaman yang diberi 0,75 liter dan tanpa diberi air beras. Jumlah daun yang dihasilkan dari pemberian air beras 1 liter tidak lebih banyak dari jumlah daun tanaman yang diberi siraman air beras 0,5 liter, namun lebih banyak dari jumlah daun tanaman dengan pemberian air beras 1,5 liter dan dan tanpa pemberian air beras. Jumlah daun yang dihasilkan dari tanaman yang diberi 0,5 liter air beras lebih banyak dari jumlah daun tanaman yang diberi air beras 1,5 liter dan tanaman yang tidak diberi air beras. Tanaman yang diberi 1,5 liter air beras menghasilkan jumlah daun yang tidak lebih banyak dari tanaman yang tidak diberi air beras.

Berat segar tanaman tertinggi pada pemberian air beras 1 liter. Pemberian air beras 0,5 liter tidak menghasilkan tanaman yang lebih berat dari tanaman yang disiram dengan pemberian 2 liter, tetapi lebih berat dari tanaman yang diberi siraman air beras dengan 1,5 liter dan yang tidak beri air beras. Berat segar tanaman yang disiram air beras dengan 2 liter tidak lebih baik dari yang disiram dengan 1,5 liter, tetapi lebih berat dari tanaman yang tidak beri air beras. Pada tanaman yang diberi air beras 1,5 liter menghasilkan berat segar tanaman yang tidak lebih baik dari tanaman yang tidak diberi dengan air beras. 


\section{PEMBAHASAN}

Pemberian air beras berpengaruh terhadap pertumbuhan dan hasil tanaman sawi hal ini diketahui dari hasil analisis terhadap tinggi tanaman, jumlah daun, dan berat segar. Pengaruh nyata ini disebabkan karena air cucian beras mengandung unsur hara. Selain itu Noor dan Yoga (2011) menyatakan bahwa air cucian beras dapat meningkatkan produksi tanaman disebabkan kandungan karbohidrat yang tinggi. Karbohidrat dapat menjadi perantara terbentuknya hormon pertumbuhan yaitu auksin dan giberelin.

Gadner, dkk menyatakan bahwa auksin berperan dalam pembentukan tunas baru, sedangkan giberelin berperan dalam pertumbuhan akar.

Volume siraman air beras tidak berpengaruh terhadap tinggi tanaman hal ini diduga karena oleh rendahnya kandungan hara yang tersedia pada air cucian beras sehingga belum mencukupi untuk pertumbuhan tinggi tanaman sawi, tetapi tidak demikian dengan pertumbuhan daun dan berat segar di mana volume siraman air beras berpengaruh nyata terhadap dua parameter tersebut.
Hasil uji BNJ diketahui bahwa pemberian air beras dengan dosis menghasilkan jumlah daun yang terbanyak meskipun tidak lebih banyak dari jumlah daun yang dihasilkan tanaman yang diberi 1 liter dan 0,5 liter. Hal ini diduga bahwa pemberian 0,5 liter air beras sudah mampu mencukupi kebutuhan tanaman dalam membentuk jaringan baru. Pembentukan jaringan baru seperti daun tidak lepas dari peran hormon pertumbuhan yang terdapat di dalam air beras. Hormon yang berperan penting dalam pembentukan tunas baru adalah auxin.

Hasil uji BNJ diketahui bahwa volume siraman air beras sebanyak 1 liter menghasilkan berat segar tertinggi, hal ini diduga berkaitan dengan kemampuan tanaman dalam mengelola hara dalam proses perkembangannya. Dengan pemberian 1 liter memungkinkan unsur-unsur hara maupun hormon pertumbuhan yang terdapat di dalam air beras cukup optimal dalam perbanyakan sel-sel tanaman sehingga berat tanaman menjadi meningkat. Elfarisna, dkk (2013:104) menyatakan bahwa air limbah cucian beras mempunyai unsur hara yang berguna bagi tanaman dalam memperbanyak jumlah sel tanaman 
mekipun jumlahnya relatif rendah, seperti unsur hara N, P, dan K. Astutik (2009) menyatakan bahwa air cucian beras juga mengandung unsur hara seperti $\mathrm{Ca}, \mathrm{Fe}, \mathrm{Mg}, \mathrm{Mn}, \mathrm{P}$, dan Zn. Ca yang berfungsi pengatur pengisapan air dari dalam tanah, berguna untuk menghilangkan racun dalam tanah, $\mathrm{Ca}$ juga berfungsi pada pertumbuhan vegetatif tanaman, unsur Ca diperlukan tanaman untuk pemanjangan sel-sel, pembelahan sel, pertumbuhan tanaman ke arah atas dan pembentukan kuncup. Selain itu kalsium juga berfungsi untuk merangsang pembentukan bulu-bulu akar, memperkeras batang tanaman dan sekaligus merangsang pembentukan biji.Fe diserap dalam bentuk ion feri $\left(\mathrm{Fe}^{++}\right)$ataupun fero $\left(\mathrm{Fe}^{++}\right) \cdot$ Besi berfungsi penting bagi pembentukan zat hijau daun (klorofil), pembentukan karbohidrat, lemak dan protein. Fe juga berperan dalam perkembangan kloroplas. Fe yang dikandung oleh air cucian beras berperan dalam pembentukan zat hijau daun, dan di daun terjadi proses fotosintesis, makanan yang dihasilkan oleh proses tersebut untuk pertumbuhan dan perkembangan tanaman.

$\mathrm{Mg}$ yang terkandung dalam air cucian beras berfungsi membantu proses pembentukan hijau daun atau klorofil, dan berperan membantu proses transportasi phosphate dalam tanaman. Mg juga berperan dalam pembentukan buah, sedangkan seng ( $\mathrm{Zn})$ berfungsi pada pembentukan hormon (auxin) dan penting bagi keseimbangan fisiologis (Sutedjo, 2008). Fungsi Mn adalah pada proses fotolisis air (penguraian air) sehingga terbentuk energi yang dapat digunakan tanaman untuk proses-proses metabolisme seperti absorbsi, transpirasi, pembelahan sel (Munawar, 2011).

\section{KESIMPULAN DAN SARAN}

Hasil pengamatan dan analisis data pada penelitian ini diambil kesimpulan sebagai berikut: Pemberian air beras berpengaruh tidak nyata terhadap pertumbuhan sawi yang diketahui dari hasil pengamatan tinggi tanaman, tetapi berpengaruh nyata terhadap jumlah daun dan berat segar tanaman. (2) Volume siraman air beras 1 liter menghasilkan jumlah daun dan berat segar tertinggi dengan rata-rata 9,80 helai per tanaman, dan 127,00 gram per tanaman. 


\section{DAFTAR PUSTAKA}

Astutik, S. 2009. Beras Cokelat atau Beras Pecah Kulit. Artikel Ilmiah Online. Diakses 15 Juni 2017.

Elfarisna, Rita Tri Puspitasari, dan Mirdad Mirdani. 2013. Pengaruh Penggunaan Air Limbah Cucian Beras Dan Miza Plus Terhadap Hasil Kedelai Edamame. Prosiding Seminar Hasil Penelitian Tanaman Aneka Kacang dan Umbi 2013.

Gadner,FP., R.Brent Perace, dan Roger L Mitchell. 1991. Terjemahan
Herawati Susilo dan Subiyanto. Fisiologi Tanaman Budidaya. Universitas Indonesia Press. Jakarta.

Munawar, A. 2011. Kesuburan Tanah dan Nutrisi Tanaman. IPB Press. Bogor.

Noor, CM., dan Y. Andesca. 2011. Buanglah Air Cucian Berasmu Dengan Baik dan Benar. Artikel. Universitas Islam Indonesia.

Sutedjo, M.M. 2008. Pupuk dan Cara Pemupukan. Rineka Cipta. Jakarta. 